МОИСЕЕВ Антон Борисович - старший преподаватель кафедры социологии и политологии Московского университета МВД России им. В.Я. Кикотя (117436, Россия, г. Москва, ул. Волгина, 12; borisyech71@mail.ru)

САЦУТА Александр Ильич - кандидат философских наук, профессор; профессор кафедры социологии и политологии Московского университета МВД России им. В.Я. Кикотя (117436, Россия, г. Москва, ул. Волгина, 12; al.satsuta@таil.ru)

\title{
ВЗАИМОДЕЙСТВИЕ ПОЛИТИЧЕСКОГО РЕЖИМА И ПРАВООХРАНИТЕЛЬНЫХ ОРГАНОВ ГОСУДАРСТВА
}

\begin{abstract}
Аннотация. В статье раскрывается содержание и характер взаимодействия политического режима и правоохранительных органов государства. Авторы выделяют особенности функционирования и деятельности правоохранительных органов при тоталитарном, авторитарном и демократическом политических режимах; характеризуют средства, способы, приемы и методы воздействия правоохранительных органов на общественную жизнь.

Ключевые слова: политический режим, правоохранительные органы государства, содержание и характер взаимодействия политического режима и правоохранительных органов государства, типы политического режима, средства, способы, методы и приемы воздействия правоохранительных органов на общественную жизнь
\end{abstract}

$\Pi^{2}$ олитический режим является важнейшей характеристикой внутренней организации, самоорганизации и саморегуляции политической системы общества, представляет способ ее функционирования, определенный порядок устройства и организации политической жизни. Это совокупность институтов, правил, средств, способов, приемов и методов, используемых государством для реализации политической (государственной) власти, регулирования общественных отношений.

Тесно взаимосвязаны и взаимодействуют с политическим режимом правоохранительные органы государства. Являясь инструментом государственной власти, обеспечивая законность и правопорядок в стране, общественную безопасность, они используют различные средства, способы, приемы и методы воздействия на общественные процессы. В зависимости от складывающейся ситуации для ее регулирования они применяют как несиловые средства и способы, так и физическую силу, как средства нелетального характера, так и огнестрельное оружие. В последние годы правоохранительные органы государств в борьбе с экстремизмом и терроризмом, трансграничной преступностью нередко взаимодействуют с вооруженными силами и на практике используют военные методы.

Место и роль правоохранительных органов государства в политической жизни общества, их взаимоотношения с политическим режимом в зарубежной политической науке рассматриваются и оцениваются по-разному [Хейвуд 2019: 478-480]. Ученые либеральной ориентации характеризуют правоохранительные органы как нейтральный политический институт, обеспечивающий охрану общественного порядка и защиту прав и свобод граждан, интересов личности, общества и государства. Сторонники консервативной позиции считают, что роль правоохранительных органов в обществе заключается в том, чтобы обеспечивать устойчивость государственной власти и безусловное исполнение законов и решений государства. Они рассматривают правоохранительные органы как силовой институт государственной власти, способный при необ- 
ходимости предельно жестко ответить на любые общественные возмущения и массовые беспорядки, оценивают их как инструмент политического контроля. Представители радикальной точки зрения оценивают правоохранительные органы как средство угнетения, выполняющее роль защиты тех, кто правит, от тех, кто не правит [Паренти 1990: 190]. В классической марксистской версии правоохранительные органы характеризовались как орудие защиты капитала и имущества эксплуататоров от эксплуатируемых.

Различия в оценке места и роли правоохранительных органов в политической жизни общества, в механизме государственной власти и политическом управлении являются основанием для выделения в западной политологии правоохранительных органов, выполняющих политическую роль, и правоохранительных органов общего назначения, что позволяет провести линию водораздела между полицейскими и либеральными государствами [Хейвуд 2019: 480]. В полицейских государствах правоохранительные органы предназначены для обеспечения господства правящей политической элиты и подавления несистемных политических сил, находящихся в оппозиции по отношению к ней. Для этого создаются органы внутренней безопасности, деятельность которых носит однозначно политический характер и ориентирована на обеспечение всестороннего контроля (при необходимости - подавления) общественных групп и отдельных лиц, которые могут представлять (представляют) угрозу для государства, с использованием как правовых, так и неправовых средств и методов.

Принято считать, что правоохранительные органы общего назначения функционируют в либеральных государствах. Они обеспечивают правопорядок и безопасность в неполитических сферах общественной жизни: защищают жизнь, здоровье и имущество граждан от преступных посягательств, регулируют дорожное движение, оказывают первую медицинскую помощь, поддерживают функционирование социальной инфраструктуры при чрезвычайном положении и чрезвычайных ситуациях, выполняют другие социально значимые задачи [Паренти 2006: 174].

На практике, как правило, правоохранительные органы общего назначения и правоохранительные органы, выполняющие политическую функцию (органы внутренней безопасности), в большинстве государств разного типа функционируют и действуют параллельно. Примером является нацистская Германия, где одновременно существовали обычная территориальная полиция и гестапо - государственная политическая полиция.

Различия между правоохранительными органами общего назначения и правоохранительными органами, выполняющими политическую (полицейскую) функцию, представляются несущественными и, по сути, сводятся лишь к разграничению сфер их правовых компетенций, установленных государством. Основное же влияние на положение и роль правоохранительных органов в обществе, в механизме реализации политической власти, на содержание и характер выполняемых ими задач оказывают правовые и политико-идеологические основания функционирования и использования правоохранительных органов при том или ином типе политического режима.

При тоталитарном политическом режиме правоохранительные органы жестко подчинены идеологии и директивным установкам правящей в обществе политической элиты или политического лидера. Управление правоохранительными органами в высочайшей степени централизовано, а их высшее руководство интегрировано в структуру высшего политического руководства страны. Законодательством им представлены самые широкие полномочия в области обеспечения правопорядка и общественной безопасности, и особенно для подавления подлинных или мнимых противников режима, включая воз- 
можность применения неограниченного морального и физического насилия по отношению к заподозренным в нелояльном отношении к существующей власти и право на осуществление внесудебной расправы. Нередко функции непосредственной защиты существующей политико-правовой системы подменяются выполнением задач карательного характера, когда обвинения в преступных деяниях определенного типа предъявляются неограниченному числу лиц без установления факта персонального участия и степени вины каждого обвиненного лица в инкриминируемом ему деянии.

При тоталитарном политическом режиме правоохранительные органы, имея совершенно избыточную власть над обществом [Хейвуд 2019: 482], поддерживают постоянную атмосферу страха в целях укрепления контроля правящей элиты над всеми сферами жизни, широко применяют для этого репрессивные методы. Но, в отличие от господствующего положения армии в обществе при военных диктатурах, правоохранительные органы при любой разновидности тоталитаризма практически никогда не играют самостоятельной, лидирующей роли в политической жизни общества, а находятся в услужении у правящего в обществе класса, партии, лидера.

Сотрудники правоохранительных органов при тоталитарном политическом режиме обладают особым социальным статусом в обществе и по сравнению с другими социальными группами, как правило, занимают привилегированное социальное положение. Особое внимание уделяется формированию у сотрудников правоохранительных органов преданности политическому режиму, исключительной лояльности власти, поддержанию в их среде обстановки бдительности, страха, для чего используются различные приемы и методы. Свидетельством этому являются «чистки» органов прокуратуры, внутренних дел и государственной безопасности, репрессии по отношению к их сотрудникам в 30-х гг. прошлого столетия в СССР.

В условиях авторитарного политического режима правоохранительные органы, обеспечивая правопорядок и общественную безопасность, выполняют практически те же задачи, что и при тоталитаризме, - выявление и наказание противников правящего класса. Но при этом их деятельность в большей степени законодательно регулируется; в частности, у правоохранительных органов отсутствует право на внесудебные репрессии. Тем не менее правоохранительные органы прямо подчиняются правящей элите и ее официальному политическому лидеру, непосредственно управляются ими и выполняют их решения. Как и при тоталитаризме, при авторитарных политических режимах правоохранительные органы осуществляют подавление оппозиционных по отношению к власти политических сил. Однако делают они это с учетом существующего общественного мнения, оправдывая свои действия законными интересами общества, стремятся заручиться его поддержкой и одобрением. В условиях авторитарных политических режимов правоохранительные органы не привлекаются к массовым репрессиям в отношении потенциальных противников власти, персональная вина которых в совершении инкриминируемых деяний не установлена. Всеобщее устрашение общества арестами, судебными и внесудебными расправами сменяется нанесением точечных ударов по лидерам и активистам оппозиции, часто не выходящим за рамки чисто административных мер, таких как штрафы, запрет на проживание в определенной местности, отказ в предоставлении права выезда за границу, краткосрочное задержание под различными предлогами.

В странах с демократическим политическим режимом организация и функционирование правоохранительных органов, их социальная роль и задачи определяются и регламентируются законодательством, механизмами правового 
регулирования, а сама их деятельность находится под жестким общественным контролем, основу которого составляет безусловное признание верховенства общепризнанных прав и свобод человека и гражданина, установленных нормами международного и национального права. От сотрудников правоохранительных органов в установленном законом порядке требуется максимальная нейтральность по отношению ко всем без исключения субъектам политической жизни общества.

Вместе с тем не исключается использование правоохранительных органов в интересах существующей власти для противодействия оппозиционным политическим силам, что обосновывается различными, как реальными, так и вымышленными, причинами (противодействие экстремизму, борьба с терроризмом). При этом уровень политизации правоохранительных органов в демократическом обществе неизменно повышается по мере того, как оно становится все более социально сложным и фрагментированным [Хейвуд 2019: 481-482]. В этих условиях границы между гражданской и политической сферами деятельности правоохранительных органов постепенно стираются: их деятельность становится политичной в той степени, в какой политично существующее в демократических обществах неравномерное распределение материальных благ, ресурсов и власти. Правоохранительные органы в силу своего предназначения обеспечивают функционирование сложившейся политической системы общества, существующего политического режима, и поэтому общество перестает верить в их нейтральность, особенно в тех случаях, когда они используются для пресечения протестных выступлений, вызванных общественными противоречиями и проблемами, затрагивающими интересы большинства членов общества. И когда это происходит, значительная часть населения не воспринимает правоохранительные органы как законную силу, а их действия - как легальные. Свидетельством этому являются события в Каталонии (Испания) осенью 2017 г. в ходе проведения и оглашения итогов референдума о предоставлении ей независимости, антиправительственные действия «желтых жилетов» в Париже в конце 2018 - начале 2019 г.

Правоохранительные органы современных демократических стран часто сталкиваются с такими социальными опасностями и бедствиями, которые просто не поддаются воображению законопослушной части их населения. Они имеют дело практически со всем спектром известных проблем постиндустриального общества, объем и сложность которых в последнее время значительно возросли [Паренти 2006: 190].

Правоохранительные органы - один из основных инструментов политической (государственной) власти. В рамках действующего правового поля или с учетом предписаний и распоряжений органов государства при любых типах политических режимов они используют широкий арсенал средств, способов, приемов и методов для воздействия на общественные процессы в интересах сохранения и укрепления власти правящих в обществе политических сил.

\section{Список литературы}

Паренти М. 1990. Демократия для немногих. М.: Прогресс. 362 с.

Паренти М. 2006. Демократия для избранных. Настольная книга о политических играх в США. М.: Поколение. 473 с.

Хейвуд Э. 2019. Политология: учебник для студентов вузов (пер. с англ.). М.: Юнити Дана. 534 с. 
MOISEEV Anton Borisovich, Senior Lecturer of the Chair of Sociology and Political Science, V.Ya. Kikot' Moscow University of the Ministry of Internal Affairs of the Russian Federation (12 Akademika Volgina St, Moscow, Russia, 117437; borisyech71@mail.ru)

SATSUTA Aleksandr Il'ich, Cand. Sci. (Philos.), Professor; Professor of the Chair of Sociology and Political Science, V.Ya. Kikot' Moscow University of the Ministry of Internal Affairs of the Russian Federation (12 Akademika Volgina St, Moscow, Russia, 117437; al.satsuta@mail.ru)

\section{INTERACTION OF POLITICAL REGIME AND LAW ENFORCEMENT AUTHORITIES}

Abstract. The paper reveals the content and nature of the interaction of political regime and law enforcement agencies of the state and shows the place and the role of law enforcement agencies in the mechanism of realization of political power. The authors highlight the conditions, factors and features of the functioning and activities of law enforcement agencies of the state under totalitarian, authoritarian and democratic political regimes, and describes the means, methods, techniques and methods of influence of law enforcement agencies on public life.

Keywords: political regime, law enforcement agencies of state, interaction of political regime and law enforcement agencies of state, types of political regime, means, techniques and methods of law enforcement agencies' influence on public life

АРТЕМЬЕВ Алексей Александрович - преподаватель кафедры политологии Военного университета Министерства обороны РФ (123001, Россия, г. Москва, ул. Большая Садовая, 14; alekseyartemev@bk.ru)

ФАТЫХОВ Шамиль Ринатович - адъюнкт кафедры политологии Военного университета Министерства обороны РФ(123001, Россия, г. Москва, ул. Большая Садовая, 14; shaт0821@таil.ru)

\section{ВЗАИМОДЕЙСТВИЕ ВООРУЖЕННЫХ СИЛ РФ И РЕЛИГИОЗНЫХ ОБЪЕДИНЕНИЙ КАК ФАКТОР ПОЛИТИЧЕСКОЙ СТАБИЛЬНОСТИ СОВРЕМЕННОГО РОССИЙСКОГО ОБЩЕСТВА}

Аннотация. В статье характеризуется взаимодействие Вооруженных сил Российской Федерации и религиозных объединений. Главный постулат авторов заключается в том, что религиозные организации России, и в первую очередь Русская православная церковь, обладая большим авторитетом в российском обществе, способны не только поддерживать свою внутреннюю устойчивую стабильность, но и при определенных условиях укреплять социальную и политическую стабильность российского общества.

Ключевые слова: политическая стабильность, политическая система, религиозные объединения, религиозные институты, Русская православная церковь, Вооруженные силы РФ, армия

$\Pi$ роисходящие в современной России социально-политические процессы свидетельствуют о значимости взаимодействия государства и религиозных объединений в построении современного российского общества. Одним из важных факторов стабильности государства и общества, их динамического развития необходимо считать духовно-нравственные основы человека. Данные качества индивида, как правило, формируются религией, которая выполняет мировоззренческую, регулятивную, воспитательную и консолидирующую функции. Возможности реализации религиозными объединениями сво- 